\title{
Research on agroforestry systems and biodiversity conservation: what can we conclude so far and what should we improve?
}

\author{
Sébastien Boinot ${ }^{1 *} \mathbb{C}$, Karim Barkaoui ${ }^{2,3}$, Delphine Mézière ${ }^{2}$, Pierre-Eric Lauri ${ }^{2}$, Jean-Pierre Sarthou ${ }^{4}$ and \\ Audrey Alignier ${ }^{1,5}$
}

\begin{abstract}
Through a meta-analysis, Mupepele et al. (BMC Ecol Evol 21:1-193, 2021) assessed the effects of European agroforestry systems on biodiversity, estimated by species richness or species diversity. They showed that the effects of silvoarable and silvopastoral systems depend on the systems they are compared to and the taxa studied. Further, they found that only silvoarable systems increased species richness or diversity, compared to cropland. The authors conclude that agroforestry systems have weak effects on biodiversity and that landscape context or land-use history are probably more important than the practice of agroforestry in itself. However, we draw attention to important shortcomings in this meta-analysis, which downplay the potential of agroforestry for biodiversity conservation in agricultural landscapes. We hope that the meta-analysis by Mupepele et al. (BMC Ecol Evol 21:1-193, 2021), and our comments, will contribute to improving the quality of research on agroforestry systems and biodiversity conservation.
\end{abstract}

Keywords: Alley cropping, Control plot, Experimental design, Farming practices, Diversity indices, Hedgerow, Metaanalysis

\section{Hedgerow systems are widespread agroforestry systems in Europe}

In their meta-analysis, Mupepele et al. [1] defined agroforestry as a "collective name for diverse land-use systems integrating tree husbandry with livestock or arable cultivation". Fields bordered by riparian fields margins and hedgerows were excluded as "they are not really under silvicultural use". However, hedgerows are widespread traditional agroforestry practices and were part of the AGFORWARD European research project (AGroFORestry that Will Advance Rural Development) [2]. We emphasize that farmers can use hedgerows for wood production and include them in their farm management.

\footnotetext{
*Correspondence: sebastien.boinot@inrae.fr

1 UMR 0980 BAGAP, INRAE-Institut Agro-ESA, 65 rue de St Brieuc CS 84215,

35042 Rennes Cedex, France

Full list of author information is available at the end of the article
}

For instance, based on a recent survey [3], 20\% of farmers plant hedgerows in Brittany. Among them, 70\% valorize the wood resulting from the maintenance of hedgerows (e.g., firewood, timber wood, wood chips, ramial-chipped wood). Hedged farmland (or bocage) are agroforestry systems with high potential to enhance the diversity of many taxa, including plants, invertebrates, birds, and mammals $[4,5]$. In European agricultural landscapes, hedgerows are particularly interesting for biodiversity conservation as they are relatively stable habitats, offering refugia and trophic resources to many living organisms [6] and references therein). Compared to modern agroforestry systems (e.g., alley cropping), there is a large body of work on hedgerows and their management, which should be accounted for in a synthesis work on agroforestry. This could only improve our knowledge of ecological processes in agroforestry systems and their impacts on biodiversity conservation. 


\section{Inadequate controls to assess the effects of agroforestry systems}

We carefully read the protocols of studies comparing agroforestry systems with arable crops or open pastures, as our primary interest is the benefit of agroforestry systems in agricultural landscapes. We found that at least 11 out of 28 studies included in the meta-analysis by Mupepele et al. [1] did not have adequate control sites. Many studies were designed to assess the distribution of taxa within agroforestry systems [7-11], not to assess the effect of agroforestry relative to other cropping systems. For instance, Boinot et al. [7] assessed the distribution of overwintering invertebrates in alley cropping systems, comparing assemblages in crop alleys vs. understory vegetation strips. Mupepele et al. then used crop alleys as cropland controls in their meta-analysis. The authors stated that "observational studies were included if a good proxy for a control site was available. This was the case for studies about species groups with limited mobility (e.g. plants or Collembola) looking at distance gradients". This argument is not valid because species with limited mobility can still be affected by the agroforestry microclimate $[12,13]$, or by biotic interactions with more mobile species. First, increased environmental heterogeneity in agroforestry systems could favor species coexistence and diversification [14]. Second, studies found that agroforestry can promote predators and seed dispersers (e.g., [15-17], and pollinators [18] and references therein). Predator partitioning, the presence of dispersal vectors, and complex plant-pollinator networks are essential for maintaining plant diversity [19-21]. It should also be emphasized that herbaceous plant species can have high dispersal abilities [22, 23]. Besides, the authors included studies with controls that are located close to the tree rows, for instance, at distances varying between 18 and $55 \mathrm{~m}$ [24], between 20 and $30 \mathrm{~m}$ [25], or even less than $10 \mathrm{~m}$ [26]. These distances are far below the dispersal range of the taxa surveyed in these studies, including airborne arthropods caught with pan traps and sticky cards or ground-dwelling arthropods such as carabids and millipedes $[27,28]$.

Beyond inadequate controls, this meta-analysis includes a mixture of studies with different approaches. Some evaluate agroforestry systems with low-intensity management as an alternative to arable crops or open pastures with high-intensity management (e.g., [29, 30], whereas others disentangle the effect of agroforestry systems per se (i.e., the benefit of trees and spontaneous vegetation) from the effect of management intensity (e.g., $[7,31])$. Besides, researchers rarely described the farming practices in agroforestry vs. control plots. The lack of a systemic approach hinders synthesis efforts such as those provided by the authors of this meta-analysis, and makes the results difficult to interpret. Overall, if the objective is to assess the effect of agroforestry per se, cropland controls should meet the following criteria to avoid confounding factors: (i) similar farming practices to that occurring in agroforestry systems (e.g., crop type, management intensity), (ii) location in the same landscape context, (iii) sufficient distance between agroforestry and cropland samples to minimize edge effects (e.g., microclimate, spillover). In all cases, farming practices should be reported as accurately as possible.

\section{Biodiversity goes beyond species counts}

In the Discussion, the authors mention that "our conclusions are largely based on species richness comparison; communities may well differ in their composition beyond richness (compare e.g. [12, 25, 32]). For conservation decisions, variables such as the occurrence of rare and endangered species may be additionally relevant". The fact that the authors draw conclusions about the effect of agroforestry systems on "biodiversity" is therefore highly misleading. As mentioned, they only considered one facet of biodiversity, species richness, which is an insufficient measure to characterize conservation areas or to describe the response of biodiversity to anthropogenic disturbances [33]. This meta-analysis does not provide information on abundance or species and functional composition, which may be severely affected. In the face of anthropogenic disturbances, the most profound changes in biodiversity are a high turnover of species and a reduction in functional diversity, whereas shifts in species richness show mixed patterns [34, 35]. Biotic homogenization can explain these results. Widespread generalist, fast-growing or invasive taxa tend to replace localized specialist, slow-growing, or threatened taxa, as they can cope or even thrive with anthropogenic disturbances [36, 37]. Such detrimental species turnover can occur without any change in species richness, or it can even lead to a punctual increase in species richness if colonization occurs more rapidly than extinctions.

We found that 22 out of 28 studies revealed effects of agroforestry systems on abundance (e.g., [31, 38-41], species composition (e.g., [40, 42-45], or ecological/ functional groups (e.g., [38, 39, 41, 46, 47]. For instance, Varah [31] found that butterflies, which are well-known indicator organisms, were about three times more diverse and three times more abundant in agroforestry systems. Boinot et al. [38] showed that alley cropping systems are refugia for plant species that are sensitive to agricultural disturbances. Gallé et al. [43] identified new species for the Romanian spider fauna under the canopy of scattered trees in wood pastures, along with species of high conservation status. Rösch et al. [40] found higher bird species richness, beta diversity, and density of breeding 
pairs in wood pastures, along with the presence of target species for conservation, as opposed to open pastures. Therefore, the authors of this meta-analysis cannot put forward that "overall, there was no benefit of agroforestry to biodiversity" or that the effects on biodiversity are "of small magnitude", when they only compared numbers of species.

\section{Too early for a meta-analysis on alley cropping agroforestry systems}

It is too early to conclude on the effect of alley cropping agroforestry systems on biodiversity conservation. Results of studies are just beginning to emerge (e.g. [15, 48-51]). Only eight studies included in this meta-analysis involved alley cropping systems. Among them, most systems were still very young. Based on studies with adequate control sites, the mean age of alley cropping systems was 8.5 years $( \pm 7.9)$. Thus, the results apply to systems in transition rather than to mature alley cropping systems. We can expect immigration credit with the development of trees [52], which could enhance biodiversity in older agroforestry systems. However, temporal studies are lacking. In this context, "before-after controlimpact" designs should be promising [53].

Further, many studies used in this meta-analysis were not designed to assess the effect of alley cropping systems on biodiversity but were restricted to taxa of interest for agricultural production, such as crop pests or their natural enemies. We question the relevance of gathering such disparate studies in a meta-analysis, giving a false impression of exhaustive sampling. Indeed, the results of such studies are unlikely to reflect the response of biodiversity to a given system, as opposed to studies encompassing many taxa (e.g., [54]. Besides, out of the eight studies, five focused on arthropods, two on plants, and one on earthworms. Information on birds, mammals, reptiles, and amphibians is missing. Further studies are needed to assess the effect of temperate agroforestry systems on these taxa, which generally depend on the presence of semi-natural habitats in the surroundings $[17,55,56]$.

Finally, in most studies, protocols were not designed to sample the full range of habitats that make up agroforestry systems. Often, this is explained by the identity of surveyed taxa and associated objectives (e.g., assessing pest pressure or biological control in crop alleys). In alley cropping systems, tree rows and associated vegetation strips were not always sampled, whereas they are crucial for biodiversity conservation. Such habitats provide refugia from agricultural disturbances (e.g., tillage, pesticide, harvest) and trophic resources $[7,57])$, and probably serve as ecological corridors or stepping stones for species that do not venture into cropland. Notably, only one study sampled arthropods directly on trees [26]. In addition, non-selective herbicide treatments prevented the growth of herbaceous flora in some cases $[25,58]$. Therefore, this meta-analysis most likely underestimates the positive effects of alley cropping systems on species diversity.

\section{Still plenty of room for improvement: the importance of local practices}

As suggested by the authors, contrasted effects of agroforestry systems could be due to the landscape context or land-use history, which are rarely reported. We emphasize that many local factors could also affect biodiversity in agroforestry systems (and should be reported as well), such as (i) the density and diversity of tree, shrub, and herbaceous layers, (ii) their age, management and spatial configuration, and (iii) farming practices (e.g., tillage management, pesticide treatment, grazing intensity, fertilization, crop rotation, cover cropping). Management of semi-natural habitats such as hedgerows strongly affects biodiversity [59]. Tree diversity is a key driver of biodiversity in forests [60], and the same could hold in agroforestry systems [e.g. 61 in the tropics]. Further, intensive farming practices in cropped areas can undermine the potential of adjacent semi-natural habitats for biodiversity conservation [32, 62]. Therefore, the current performance of agroforestry systems is probably far from optimal, but studies on the effects of management at both local and landscape scales are lacking.

\section{Conclusion}

Despite the strong enthusiasm of the agroforestry research community, a recent systematic review of agroforestry experiments in the Global South concludes that rigorous evidence on the effects of agroforestry on agricultural productivity, ecosystem services, and human well-being remains extremely limited [63]. Similarly, through their meta-analysis, Mupepele et al. [1] point out that we should not take for granted the positive effects of agroforestry on biodiversity. We add that we should not prematurely underestimate the potential of agroforestry either. There are reasons to be enthusiastic because many studies revealed tremendous impacts of agroforestry systems on the abundance, evenness, and composition of communities, which are all important facets of biodiversity. Future research on biodiversity conservation in agroforestry systems should (i) continue to go beyond species diversity by considering abundance and species, functional or genetic composition, (ii) encompass more taxa (e.g., micro-organisms, mammals, reptiles, and amphibians that are missing in this meta-analysis, (iii) assess the effects of local factors such as habitat management, spatial configuration, and farming practices, on which farmers can directly act, and (iv) assess the influence 
of land-use history and landscape context on agroforestry performance. To improve the quality of agroforestry research, we must take care developing rigorous experimental designs with adequate controls. Patience is also necessary; we have to wait for agroforestry systems to grow before jumping to meta-analyses and hasty conclusions.

\section{Acknowledgements}

SB would like to thank La Fondation de France for funding his postdoctoral research, and two anonymous reviewers for their very constructive comments.

\section{Authors' contributions}

SB led the writing of the manuscript. KB, DM, PEL, JPS and AA contributed to the drafts. All authors have read and approved the manuscript.

\section{Funding}

La Fondation de France supports the postdoctoral research of SB (DIVERSIT'HAIES project).

\section{Availability of data and materials}

Not applicable.

\section{Declarations}

\section{Ethics approval and consent to participate}

Not applicable. No human participants, human material, or human data were used for this correspondence article.

\section{Consent for publication}

Not applicable.

\section{Competing interests}

The authors declare that they have no competing interests.

\section{Author details}

${ }^{1}$ UMR 0980 BAGAP, INRAE-Institut Agro-ESA, 65 rue de St Brieuc CS 84215 , 35042 Rennes Cedex, France. ${ }^{2}$ ABSys, Univ Montpellier, CIHEAMIAMM, CIRAD, INRAE, Institut Agro, Montpellier, France. ${ }^{3}$ CIRAD, UMR ABSys, Montpellier, France. ${ }^{4}$ University of Toulouse, INRAE, INPT-ENSAT, UMR AGIR, 31326 Castanet-Tolosan, France. ${ }^{5}$ LTSER « Zone Atelier Armorique », 35042 Rennes, France.

Received: 8 December 2021 Accepted: 20 February 2022

Published online: 03 March 2022

\section{References}

1. Mupepele A-C, Keller M, Dormann CF. European agroforestry has no unequivocal effect on biodiversity: a time-cumulative meta-analysis. BMC Ecol Evol. 2021;21(1):193. https://doi.org/10.1186/s12862-021-01911-9.

2. Burgess PJ, Rosati A. Advances in European agroforestry: results from the AGFORWARD project. Agroforest Syst. 2018;92(4):801-10. https://doi.org/ 10.1007/s10457-018-0261-3.

3. Toussaint M, Darrot C (2021) Enquête sociologique auprès des agriculteurs planteurs de bocage: Rapport d'étude-Juin 2021. Institut Agro Agrocampus Ouest_-UMR CNRS 6590 ESO, 149 pp. hal-03277645.

4. Alignier A, Uroy L, Aviron S. The role of hedgerows in supporting biodiversity and other ecosystem services in intensively managed agricultural landscapes. In: Bàrberi P, Moonen A-C, editors. Reconciling agricultural production with biodiversity conservation. Cambridge, UK: Burleigh Dodds Science Publishing; 2020. p. 177-204.

5. Moreno G, Aviron S, Berg S, Crous-Duran J, Franca A, de Jalón SG, Hartel T, Mirck J, Pantera A, Palma JHN, Paulo JA, Re GA, Sanna F, Thenail C, Varga $A$, Viaud V, Burgess PJ. Agroforestry systems of high nature and cultural value in Europe: provision of commercial goods and other ecosystem services. Agrofor Syst. 2018;92(4):877-91. https://doi.org/10.1007/ s10457-017-0126-1.
6. Dover JW, editor. The ecology of hedgerows and field margins. New York, USA: Routledge; 2019.

7. Boinot S, Poulmarc'h J, Mézière D, Lauri P-É, Sarthou J-P. Distribution of overwintering invertebrates in temperate agroforestry systems: implications for biodiversity conservation and biological control of crop pests. Agric Ecosyst Environ. 2019;285: 106630. https://doi.org/10.1016/j.agee. 2019.106630

8. López-Carrasco C, López-Sánchez A, San Miguel A, Roig S. The effect of tree cover on the biomass and diversity of the herbaceous layer in a Mediterranean dehesa. Grass Forage Sci. 2015;70(4):639-50. https://doi. org/10.1111/gfs.12161.

9. López-Sánchez A, San Miguel A, Dirzo R, Roig S. Scattered trees and livestock grazing as keystones organisms for sustainable use and conservation of Mediterranean dehesas. J Nat Conserv. 2016;33:58-67. https://doi. org/10.1016/j.jnc.2016.07.003.

10. López-Sánchez A, San Miguel A, López-Carrasco C, Huntsinger L, Roig S. The important role of scattered trees on the herbaceous diversity of a grazed Mediterranean dehesa. Acta Oecol. 2016;76:31-8. https://doi.org/ 10.1016/j.actao.2016.08.003

11. Rossetti I, Bagella S, Cappai C, Caria MC, Lai R, Roggero PP, Martins da Silva P, Sousa JP, Querner P, Seddaiu G. Isolated cork oak trees affect soil properties and biodiversity in a Mediterranean wooded grassland. Agric Ecosyst Environ. 2015;202:203-16. https://doi.org/10.1016/j.agee.2015.01. 008.

12. Forman RTT, Baudry J. Hedgerows and hedgerow networks in landscape ecology. Environ Manage. 1984;8(6):495-510. https://doi.org/10.1007/ BF01871575.

13. Gosme M, Dufour L, Inurreta Aguirre HD, Dupraz C (2016) Microclimatic effect of agroforestry on diurnal temperature cycle, In European Agroforestry Conference. Celebrating 20 years of Agroforestry research in Europe. European Agroforestry Conference, Montpellier, France. 23-25 March, pp. 182-185.

14. Stein A, Gerstner K, Kreft H. Environmental heterogeneity as a universal driver of species richness across taxa, biomes and spatial scales. Ecol Lett. 2014;17(7):866-80. https://doi.org/10.1111/ele.12277.

15. Boinot S, Mézière D, Poulmarc'h J, Saintilan A, Lauri P-E, Sarthou J-P. Promoting generalist predators of crop pests in alley cropping agroforestry fields: farming system matters. Ecol Eng. 2020;158: 106041. https://doi. org/10.1016/j.ecoleng.2020.106041

16. Gibbs S, Koblents H, Coleman B, Gordon A, Thevathasan N, Wiliams P. Avian diversity in a temperate tree-based intercropping system from inception to now. Agroforest Syst. 2016;90(5):905-16. https://doi.org/10. 1007/s10457-016-9901-7.

17. Klaa K, Mill PJ, Incoll LD. Distribution of small mammals in a silvoarable agroforestry system in Northern England. Agrofor Syst. 2005;63:101-10.

18. Bentrup G, Hopwood J, Adamson NL, Vaughan M. Temperate agroforestry systems and insect pollinators: a review. Forests. 2019;10(11):981. https:// doi.org/10.3390/f10110981.

19. Fontaine C, Dajoz I, Meriguet J, Loreau M. Functional diversity of plantpollinator interaction webs enhances the persistence of plant communities. PLoS Biol. 2006;4(1): e1. https://doi.org/10.1371/journal.pbio.00400 01.

20. Hulme PE. Post-dispersal seed predation: consequences for plant demography and evolution. Perspect Plant Ecol Evol Syst. 1998;1 (1):32-46. https://doi.org/10.1078/1433-8319-00050.

21. Ozinga WA, Römermann C, Bekker RM, Prinzing A, Tamis WLM, Schaminée JHJ, Hennekens SM, Thompson K, Poschlod P, Kleyer M, Bakker JP, van Groenendael JM. Dispersal failure contributes to plant losses in NW Europe. Ecol Lett. 2009;12(1):66-74. https://doi.org/10.1111/j.1461-0248. 2008.01261.x

22. Bullock JM, Mallada González L, Tamme R, Götzenberger L, White SM, Pärtel M, Hooftman DAP. A synthesis of empirical plant dispersal kernels. J Ecol. 2017;105(1):6-19. https://doi.org/10.1111/1365-2745.12666.

23. Vittoz P, Engler R. Seed dispersal distances: a typology based on dispersal modes and plant traits. Bot Helv. 2007;117(2):109-24. https://doi.org/10. 1007/s00035-007-0797-8.

24. Pardon P, Reheul D, Mertens J, Reubens B, De Frenne P, De Smedt P, Proesmans W, van Vooren L, Verheyen K. Gradients in abundance and diversity of ground dwelling arthropods as a function of distance to tree rows in temperate arable agroforestry systems. Agric Ecosyst Environ. 2019;270271:114-28. https://doi.org/10.1016/j.agee.2018.10.017. 
25. Peng RK, Incoll LD, Sutton SL, Wright C, Chadwick A. Diversity of airborne arthropods in a silvoarable agroforestry system. J Appl Ecol. 1993;30:551-62.

26. Akbulut S, Keten A, Stamps WT. Effect of alley cropping on crops and arthropod diversity in Duzce, Turkey. J Agron Crop Sci. 2003;189(4):261-9. https:// doi.org/10.1046/j.1439-037X.2003.00042.x.

27. Rodríguez-Gasol N, Alins G, Veronesi ER, Wratten S. The ecology of predatory hoverflies as ecosystem-service providers in agricultural systems. Biol Control. 2020;151: 104405. https://doi.org/10.1016/j.biocontrol.2020.104405.

28. Thiele H-U. Carabid beetles in their environment: a study on habitat selection by adaptations in phisiology and behaviour. Zoophysiol Ecol. 1977;10:1-369. https://doi.org/10.1007/978-3-642-81154-8.

29. Altieri MA, Nicholls Cl. The simplification of traditional vineyard based agroforests in northwestern Portugal: some ecological implications. Agroforest Syst. 2002;56:185-91.

30. Stoate C, Araújo M, Borralho R. Conservation of european farmland birds: abundance and species diversity. Ornis Hungarica. 2003;12:33-40.

31. Varah A (2015) Can agroforestry reconcile conflicting demands for productivity, biodiversity conservation and delivery of ecosystem services? Ph.D. thesis, $312 \mathrm{pp}$.

32. Pelosi C, Bertrand C, Daniele G, Coeurdassier M, Benoit P, Nélieu S, Lafay F, Bretagnolle V, Gaba S, Vulliet E, Fritsch C. Residues of currently used pesticides in soils and earthworms: a silent threat? Agric Ecosyst Environ. 2021;305: 107167. https://doi.org/10.1016/j.agee.2020.107167.

33. Fleishman E, Noss R, Noon B. Utility and limitations of species richness metrics for conservation planning. Ecol Indic. 2006;6(3):543-53. https://doi. org/10.1016/j.ecolind.2005.07.005.

34. Blowes SA, Supp SR, Antão LH, Bates AE, Bruelheide H, Chase JM, Moyes F, Magurran AE, McGill BJ, Myers-Smith IH, Winter M, Bjorkman AD, Bowler DE, Byrnes JE, Gonzalez A, Hines J, Isbell F, Jones HP, Navarro LM, Thompson PL, Vellend M, Waldock CA, Dornelas M. The geography of biodiversity change in marine and terrestrial assemblages. Science. 2019;366:339-45.

35. Cadotte MW, Carscadden K, Mirotchnick N. Beyond species: functional diversity and the maintenance of ecological processes and services. J Appl Ecol. 2011;48:1079-87. https://doi.org/10.1111/j.1365-2664.2011.02048.x

36. Clavel J, Julliard R, Devictor V. Worldwide decline of specialist species: toward a global functional homogenization? Front Ecol Environ. 2011;9(4):222-8. https://doi.org/10.1890/080216.

37. Gamez-Virués S, Perović DJ, Gossner MM, Börschig C, Blüthgen N, de Jong $\mathrm{H}$, Simons NK, Klein A-M, Krauss J, Maier G, Scherber C, Steckel J, Rothenwöhrer C, Steffan-Dewenter I, Weiner CN, Weisser W, Werner M, Tscharntke T, Westphal C. Landscape simplification filters species traits and drives biotic homogenization. Nat Commun. 2015;6:8568. https://doi.org/10.1038/ ncomms9568

38. Boinot S, Fried G, Storkey J, Metcalfe H, Barkaoui K, Lauri P-É, Mézière D. Alley cropping agroforestry systems: reservoirs for weeds or refugia for plant diversity? Agric Ecosyst Environ. 2019a;284: 106584. https://doi.org/10. 1016/j.agee.2019.106584.

39. Cardinael R, Hoeffner K, Chenu C, Chevallier T, Béral C, Dewisme A, Cluzeau D. Spatial variation of earthworm communities and soil organic carbon in temperate agroforestry. Biol Fertil Soils. 2019;55(2):171-83. https://doi.org/ 10.1007/s00374-018-1332-3.

40. Rösch V, Hoffmann M, Diehl U, Entling MH. The value of newly created wood pastures for bird and grasshopper conservation. Biol Conserv. 2019;237:493503. https://doi.org/10.1016/j.biocon.2019.07.036.

41. Wood H, Lindborg R, Jakobsson S. European Union tree density limits do not reflect bat diversity in wood-pastures. Biol Conserv. 2017;210:60-71. https://doi.org/10.1016/j.biocon.2017.04.001.

42. Bagella S, Filigheddu R, Caria MC, Girlanda M, Roggero PP. Contrasting land uses in Mediterranean agro-silvo-pastoral systems generated patchy diversity patterns of vascular plants and below-ground microorganisms. CR Biol. 2014;337(12):717-24. https://doi.org/10.1016/j.crvi.2014.09.005.

43. Gallé R, Urák I, Nikolett G-S, Hartel T. Sparse trees and shrubs confers a high biodiversity to pastures: case study on spiders from Transylvania. PLoS ONE. 2017;12(9): e0183465. https://doi.org/10.1371/journal.pone.0183465.

44. Giordani P, Incerti G, Rizzi G, Ginaldi F, Viglione S, Rellini I, Brunialti G, Malaspina P, Modeneso P. Land use intensity drives the local variation of lichen diversity in Mediterranean ecosystems sensitive to desertification. Bibliotheca Lichenol. 2010;105:139-48.

45. Hartel T, Hanspach J, Abson DJ, Máthé O, Moga Cl, Fischer J. Bird communities in traditional wood-pastures with changing management in Eastern
Europe. Basic Appl Ecol. 2014;15(5):385-95. https://doi.org/10.1016/j.baae. 2014.06.007.

46. Pereira P, Godinho C, Gomes M, Rabaça JE. The importance of the surroundings: are bird communities of riparian galleries influenced by agroforestry matrices in SW Iberian Peninsula? Ann For Sci. 2014;71(1):33-41. https://doi. org/10.1007/s13595-012-0228-X.

47. Tölgyesi C, Bátori Z, Gallé R, Urák I, Hartel T. Shrub encroachment under the trees diversifies the herb layer in a Romanian silvopastoral system. Rangel Ecol Manage. 2018;71(5):571-7. https://doi.org/10.1016/j.rama.2017.09.004.

48. Beule L, Karlovsky P. Tree rows in temperate agroforestry croplands alter the composition of soil bacterial communities. PLOS ONE. 2021;16(2): e0246919. https://doi.org/10.1371/journal.pone.0246919.

49. D’Hervilly C, Bertrand I, Capowiez Y, Béral C, Delapré-Cosset L, Marsden C. Seasonal variations in macrofauna distribution according to the distance from a herbaceous strip in a Mediterranean alley cropping plot. Appl Soil Ecol. 2022;170: 104309. https://doi.org/10.1016/j.apsoil.2021.104309.

50. Graham JB, Nassauer JI. Wild bee abundance in temperate agroforestry landscapes: assessing effects of alley crop composition, landscape configuration, and agroforestry area. Agroforest Syst. 2019;93(3):837-50. https://doi. org/10.1007/s10457-017-0179-1.

51. Staton T, Walters RJ, Smith J, Breeze TD, Girling RD. Evaluating a trait-based approach to compare natural enemy and pest communities in agroforestry vs arable systems. Ecol Appl. 2021;31: e02294. https://doi.org/10.1002/eap. 2294.

52. Jackson ST, Sax DF. Balancing biodiversity in a changing environment: extinction debt, immigration credit and species turnover. Trends Ecol Evol. 2010;25(3):153-60. https://doi.org/10.1016/j.tree.2009.10.001.

53. Christie AP, Amano T, Martin PA, Shackelford GE, Simmons BI, Sutherland WJ. Simple study designs in ecology produce inaccurate estimates of biodiversity responses. J Appl Ecol. 2019;56(12):2742-54. https://doi.org/10.1111/ 1365-2664.13499.

54. Lecq S, Loisel A, Bonnet X. Non-lethal rapid biodiversity assessment. Ecol Indic. 2015;58:216-24. https://doi.org/10.1016/j.ecolind.2015.06.004.

55. Rotem G, Giladi I, Bouskila A, Ziv Y. Scale-dependent correlates of reptile communities in natural patches within a fragmented agroecosystem. Landsc Ecol. 2020;35:2339-55. https://doi.org/10.1007/s10980-020-01091-9.

56. Tanadini M, Schmidt BR, Meier P, Pellet J, Perrin N. Maintenance of biodiversity in vineyard-dominated landscapes: a case study on larval salamanders. Anim Conserv. 2012;15(2):136-41. https://doi.org/10.1111/j.1469-1795.2011. 00492.x.

57. Stamps WT, Linit MJ. Plant diversity and arthropod communities: Implications for temperate agroforestry. Agrofor Syst. 1998;39:73-89.

58. Peng RK, Sutton SL. The activity and diversity of ground arthropods in an agroforestry system. Proc N Zeal Plant Protect Soc. 1996;49:309-13.

59. Graham L, Gaulton R, Gerard F, Staley JT. The influence of hedgerow structural condition on wildlife habitat provision in farmed landscapes. Biol Conserv. 2018:220:122-31.

60. Ampoorter E, Barbaro L, Jactel H, Baeten L, Boberg J, Carnol M, Castagneyrol B, Charbonnier Y, Dawud SM, Deconchat M, De Smedt P, de Wandeler H, Guyot V, Hättenschwiler S, Joly F-X, Koricheva J, Milligan H, Muys B, Nguyen $D$, Ratcliffe S, Raulund-Rasmussen K, Scherer-Lorenzen M, van der Plas F, van Keer J, Verheyen K, Vesterdal L, Allan E. Tree diversity is key for promoting the diversity and abundance of forest-associated taxa in Europe. Oikos. 2020;129(2):133-46. https://doi.org/10.1111/oik.06290.

61. Santos PZF, Crouzeilles R, Sansevero JBB. Can agroforestry systems enhance biodiversity and ecosystem service provision in agricultural landscapes? A meta-analysis for the Brazilian Atlantic Forest. Forest Ecol Manag. 2019;433:140-5. https://doi.org/10.1016/j.foreco.2018.10.064.

62. Boinot $S$, Alignier A. On the restoration of hedgerow ground vegetation: Local and landscape drivers of plant diversity and weed colonization. J Environ Manag. 2022;307:1 14530. https://doi.org/10.1016/j.jenvman.2022. 114530.

63. Miller DC, Ordoñez PJ, Brown SE, Forrest S, Nava NJ, Hughes K, Baylis K. The impacts of agroforestry on agricultural productivity, ecosystem services, and human well-being in low-and middle-income countries: an evidence and gap map. Campbell Syst Rev. 2020;16(1): e1066. https://doi. org/10.1002/cl2.1066. 


\section{Publisher's Note}

Springer Nature remains neutral with regard to jurisdictional claims in published maps and institutional affiliations.

- fast, convenient online submission

- thorough peer review by experienced researchers in your field

- rapid publication on acceptance

- support for research data, including large and complex data types

- gold Open Access which fosters wider collaboration and increased citations

- maximum visibility for your research: over $100 \mathrm{M}$ website views per year

At BMC, research is always in progress.

Learn more biomedcentral.com/submissions 